\title{
Marketing Strategies to Use Solar Energy in Homes
}

\author{
Rickey Luckett1, Charles Needham² \\ ${ }^{1}$ Grand Canyon University, Phoenix, AZ, USA \\ ${ }^{2}$ Liberty University, Lynchburg, VA, USA \\ Email: rickeyluckett@yahoo.com
}

How to cite this paper: Luckett, R., \& Needham, C. (2021). Marketing Strategies to Use Solar Energy in Homes. Open Journal of Business and Management, 9, 2950-2976. https://doi.org/10.4236/ojbm.2021.96165

Received: September 16, 2021

Accepted: November 20, 2021

Published: November 23, 2021

Copyright (c) 2021 by author(s) and Scientific Research Publishing Inc. This work is licensed under the Creative Commons Attribution International License (CC BY 4.0).

http://creativecommons.org/licenses/by/4.0/

\begin{abstract}
Grounded in the disruptive innovation theory in this single case study, the purpose of this case study was to explore homeowner's awareness of the benefits of solar energy. Twenty residential homeowners were interviewed faceto-face to explore: 1) perceived benefits of solar energy in their county in Ohio and 2) perceptions of the rationale behind the marketing strategy of solar energy systems sold for residential use. Inductive analyses and coding interpretation to explore the participants' responses revealed 3 themes: the existence of environmental benefits for using solar energy systems, the expensive cost of equipment associated with government incentives, and the lack of marketing information available for consumers use. The study's finding indicated that homeowners were largely unaware of the lack of marketing strategies and social change implications through community awareness. The implications for positive social change include the potential to enable corporate leaders, small business owners, and entrepreneurs to develop marketing strategies for renewable energy systems. These strategies may promote solar energy systems as a clean, renewable, and affordable alternative electrical energy source for the 21 st century.
\end{abstract}

\section{Keywords}

Clean Energy, Photovoltaic Panels, Photovoltaic System, Renewable Energy Solar Electricity

\section{Introduction}

In 2011, an International Energy Agency report indicated that solar panel installations would supply around 45\% of energy demand by 2050 (Mekhilef et al., 2011). The need for energy continues to rise, and communities across the coun- 
try are increasingly looking to renewable sources, for example, sun and wind, to meet demands with clean, safe, reliable energy (U. S. Department of Energy, 2021). The rapid decline in the cost of purchasing solar energy systems, combined with federal, state, and local policy changes, introduced the topic of solar energy into the mainstream. Solar energy systems are available for home use, allowing homeowners to unlock the power of these renewable resources systems. Photovoltaic (PV) systems provide a viable choice for renewable energy sources and energyefficient systems that produce electricity and heat and reduce the carbon emissions footprint on the environment (Lupangu \& Bansal, 2017). The level of residential homeowners' understanding of alternative energy systems and available resources became apparent. Business leaders can use the case study data for information based on real-world views of participants. Researchers can explore a phenomenon within its context using various data sources (Yin, 2018). The exploration of the level of awareness regarding alternative energy systems used the following research approach:

1) Identify the phenomenon by understanding homeowners' awareness regarding the availability of solar energy systems.

2) Interview the residential homeowners in the designated population area.

3) Transcribe the interviews to gain an understanding of the participants' life involved with the identified phenomenon.

4) Analyze data to identify themes and patterns.

The study included the methodology and tools for analyzing what residential homeowners interpreted and viewed as the phenomenon. Section 1 of this study consists of the introduction and background, statement, purpose, research questions, assumption, limitations, delimitations, study's significance, and literature review. The second section includes the methodology, findings, inclusions, and implications for further research.

\subsection{Purpose Statement}

The purpose of this qualitative case study was to investigate residential homeowners' views of the marketing strategy of solar energy systems sold for residential use. In addition, the area of the study was to explore marketing strategies for conveying information to homeowners about access to new solar energy products in Franklin County, OH.

\subsection{Research Question}

The central research question guided the study: Why are residential homeowners not aware of the benefits of solar energy? Data derived from observation, in-depth interviews, and the literature.

\subsection{Assumptions, Limitations and Delimitations}

In this study, several assumptions existed: 1) the participant ability to remember and provide historical information, 2) the participants answered the questions 
truthfully, 3) the study participants might be reluctant to disclose their opinions due to the potential negative repercussions, and 4) answer any or all the questions at their discretion. The assumptions helped to mitigate the risks of dishonesty in participant responses and the study consent form. The focus of this study was limited to the Franklin County housing community. The level of understanding regarding the marketing of solar-energy systems for residential purposes might not resemble the same phenomenon in other Ohioan counties. The limitations of this study were: 1) number of homeowners, 2) homeowners providing accurate information, and 3) appropriate location. The study participants were limited to residential homeowners residing in targeted communities within Franklin County, $\mathrm{OH}$. The number of residential homeowners willing and available to participate determines the study's limits and the ability to extrapolate the results to a general population of $1,195,537$. The delimitations were the interview of twenty residential homeowners provided sufficient numbers to reach the thematic saturation threshold. The participants understood how the lack of marketing solar energy systems limited their exposure to a new alternative electrical energy source (Yin, 2018).

\subsection{Significance of the Study}

The goal of the case study was to interview residential homeowners to learn more about the impact of social change in Franklin County, OH. The study is significant because of a gap in the empirical literature regarding alternative energy systems, such as solar-energy systems, and marketing for residential use. The study findings increase the information about solar industry marketing strategies for business leaders in solar industries. The intent was the following on 1) level of awareness exhibited by the homeowners regarding the implementation of marketing strategies targeted toward solar energy systems for residential, 2) implications of the problem due to rising energy costs, and 3) solutions to make solar electricity competitive with conventional forms of fossil fuels. The study is a catalyst for social change by presenting a plan for business leaders in the solar industry to educate community residents about sustainable developments in solar energy systems and guidelines adopted by the housing industry.

The research study helped to fill a gap in the literature exploring the U. S. solar energy market. Literature searches discovered no previous studies of this nature that focus on small communities in Ohio. Electricity generation became the most critical factor in developing the modern global economy and remained closely linked to human and economic development (Bazmi \& Zahedi, 2011). The U. S. solar market's greatest challenge is increased demand for the production and distribution of solar-energy technology (Abareshi, 2011). The awareness and production of solar energy systems drive the price down with traditional fossil-fuel sources (Abareshi, 2011). In addition, solar energy can produce energy on a distributed basis, called distributed generation, with equipment on rooftops or ground-mounted fixtures (Arizona Solar Energy Association, 2021). 
As the solar PV industry matures, the economic feasibility of PV projects evaluated according to the cost of electricity generation will compare favorably to other electricity generation technologies (Branker et al., 2011).

The implications for positive social change include the potential to shape research on sociotechnical issues such as solar energy and highlight the dynamics between technology and social change (Ulsrud et al., 2011). The advancement of solar technologies has created gradual changes in the sociotechnical system, including people, business practices, knowledge, and other elements, all of which require adjustments (Davis et al., 2013). This study is significant because it provides information to consumers regarding solar-energy systems and energy independence. Fossil fuels are depleting the planet's ozone layer at an increasing rate that will eventually make life unsustainable and the world unfit for human habitation (Curtiss \& Eustis, 2008). The adoption of solar energy is the market's driving force in energy creation, which has become the leading environmental issue and global warming. Solar energy is a clean, reusable, and affordable solution recognized as one of the top alternative energy sources for the 21 st century (Chen et al., 2017).

\subsection{A Review of the Academic Literature}

\section{Disruptive Innovation Theory}

Christensen (1997) created the theory of disruptive innovation on the management of technological innovation. The idea of disruptive innovation is an innovation that creates new markets or services, which continues to disrupt an existing market over several years or decades by displacing the technology of established business competitors (Christensen, 1997). The disruptive innovation theory relates to this qualitative case study because the approach assists a researcher in addressing consumers' access to new products or services. In addition, the theory of disruptive innovation allows a researcher to focus on the same premise of disruptive innovation of energy technologies related to coal, oil, or natural gas (Christensen, 1997).

Disruptive businesses in the initial stage included smaller target markets, lower gross margins, relatively unattractive services, and more straightforward products compared to traditional performance metrics (Christensen, 1997). A reflective review of disruptive innovation theory happens in a process. These types of disruptive technologies provided a different value than mainstream technologies. Compared to the mainstream market, these innovations were initially inferior along the dimensions of high performance, which were critical indicators for mainstream customers (Dan \& Hang, 2010).

One fundamental aspect of Christensen's theory of disruptive innovation was plotting product performance over time. The performance of the disruptive technology remained inferior compared with the performance offered by the established mainstream technology (Dan \& Hang, 2010). Many businesses were self-motivated to invent products on a faster innovation cycle, and some cus- 
tomers could adjust quickly to newly improved innovation cycles (Christensen, 1997). Disruptive innovation technologies were rarely disruptive to customers, and a lag time exists until the disruptive effect impacts mainstream companies (Dan \& Hang, 2010). Christensen's theory concluded that existing companies could overcome the onslaught by seeking out new business acquisitions, adapting to the innovations, and changing the business model to reflect the changing marketplace and the disruptive technologies.

\section{History of PV Cells}

The PV cell is a nonorganic process of converting light into energy in electricity (National Renewable Energy Laboratory, 2012). The Greek term phos means light. The second half of the term, volt, is named after Alessandro Volta, one of the pioneers who studied electricity. Thus, the term photovoltaics roughly translates as light electricity. The solar cell, commonly known in the world as PV systems become an essential part of people's lives. PV is absorbing and converting sunlight into an electrical energy current and storing it for later use (Mäki et al., 2011). The light absorption that fuels the PV process has no moving parts is environmentally benign and involves no equipment that can wear out.

The $P V$ effect, discovered by Edmund Bequerel in 1839, led to several modern discoveries and the development of PV devices and photographic application techniques (Lukasiak \& Jakubowski, 2010). During the 1950s, the emergence of the silicon industry created the first silicon solar cell with an initial energy efficiency index of $6 \%$. Space projects adopted these early solar cells as a source of power in satellites and spacecraft. The energy crises of the 1970s spurred interest in the potential of PV for other commercial applications (National Renewable Energy Laboratory, 2012).

\section{Solar Power Systems}

Many consumers require information about commercial PV systems so that they can make an intelligent investment that best suits their energy needs. The PV systems are grouped based on how autonomous the system is from the electrical grid. The consumer can choose from three types of PV systems: a grid inter-tied system, grid inter-tied with battery backup, and off-grid PV systems (National Renewable Energy Laboratory, 2012).

The essential components of a PV system are solar cell panels. The solar cell panels work when the sun's radiant energy strikes the PV panels and converts light into an electric current, with the semi-conductors exhibiting some limited PV effects. The scientific principle was first discovered in 1839, but more than 50 years passed before the first solar cell was built. The solar cell is the necessary component needed to harness the sun's radiant electron emissions and focus them into a usable electric current (National Renewable Energy Laboratory, 2012). Nevertheless, homeowners want to get the most from their energy devices; they want devices that will enhance their ability to harvest energy and get the highest degree of wattage to produce electricity from solar PV installations. As a result, the solar industry's marketing strategy has mainly been focusing on 
commercial buildings.

In contrast, PV systems receive classification according to use, such as thermal applications and electricity production (Lupangu \& Bansal, 2017). PV and thermal systems receive measurements based on thermal output. In a follow-up study, the characteristic performance of PV-thermal and PV systems relies on electrical energy and energy efficiencies (Lupangu \& Bansal, 2017). The PV system converts solar energy into direct current electrical power, and PV-thermal systems use the thermal energy of the solar radiation to generate electrical energy.

\section{Types of Solar Panel Materials}

The essential components of a PV system are solar cell panels. The solar cell panels use the sun's radiant energy by striking the PV panels and converting that energy into an electric current. The electrons produced by the sun's radiant energy cause limited PV effects (U. S. Department of Energy, 2021). Solar panels come in many sizes and shapes for commercial and residential use. A solar panel is composed of several grids of solar cells. The types of solar panel cells received consideration when purchasing a solar system: mono-crystalline, polycrystalline, and amorphous (National Renewable Energy Laboratory, 2012). The development of marketable solar cells continued with organic PV panels (Nayak et al., 2019). Solar cells are identified as a new technology with many features for commercialization.

\section{Types of Panels}

Solar panels are available in several types in the marketplace with different application purposes (Abdulrazzaq \& Ali, 2018). The solar panel applications included PV panels, solar water heating panels for warm climates, solar water, and radiant heating panels for cold temperatures. The development of PV technology-focused only on improving the efficiency of the cells and reducing the modules' production cost. Moreover, such variety in technology is needed to enhance solar energy deployment for a greener and cleaner environment (Moustakas et al., 2020).

The US Department of Energy's Solar Energy Technologies Program (SETP) collaborates with other national laboratories, academic institutions, and businesses across the solar-energy industry to develop a cost-competitive solar energy system (U. S. Department of Energy, 2021). The SETP objective is to advance the research and development in PV technology to reach investment-cost competitiveness by 2015. The PV technology brings new products that meet longterm carbon reduction goals and maintain a stable PV manufacturing base. SETP's ultimate effort was to focus on making PV technology competitive and cost-effective in generating electricity with conventional utility-grid electricity costs (U. S. Department of Energy, 2021).

\section{Lifecycle and Environmental Performance of Silicon Solar Panels}

The lifecycle environmental performance of solar panel production included the gas emissions from energy generation, recycled water consumption, hazard- 
ous byproducts released from production, and production waste material (Meadowcroft et al., 2018). The positive lifecycle environment performance is free emission energy that eliminates the emissions of carbon pollutants in the energy generation produced from coal and natural gas. Therefore, the positive impacts outweigh any negative concerns from an environmental perspective in producing and recycling silicon panels. In Catalonia, Italy, lifecycle analysis of PV systems was an essential component with an assessment tool to measure the potential environmental impact of using solar technologies compared to traditional technologies (Meadowcroft et al., 2018). The assessment tool is especially beneficial for technologies, depending on non-renewable fossil fuel sources, including fabrication of PV system components, raw materials used for production, and installation.

Researchers specializing in PV technologies have indicated that silicon panels generate only a small amount of toxic air emissions concerning conventional fossil fuel-generated technologies (Abdulrazzaq \& Ali, 2018). Abdulrazzaq and Ali (2018) indicated that $89 \%$ of poisonous emissions are associated with electricity generation. The process is preventable if electricity comes from PV and is displaced from the grid. PV electricity is ten times lower in emission than electricity produced from a coal-fired plant, but four times higher when compared to a nuclear power plant or a wind farm (Uddin et al., 2017). Solar panels contributed to an $89 \%$ reduction in greenhouse gas emissions and a $60 \%$ reduction in electricity produced from the national grid mix (Abdulrazzaq \& Ali, 2018). Based on the national energy grid mix, the production of 1,000 kilowatts per hour of solar electricity can eliminate sulfur dioxide, nitrogen oxides, and carbon dioxide (National Renewable Energy Laboratory, 2012).

\section{Benefits of Solar PV Panels}

Most residential homes powered by the local utility company most likely use a coal-fired power plant that burns fossil fuels and emits carbon dioxide and air pollution. When homeowners installed solar panels on their rooftops to produce electricity, they transformed the house into a green power plant of renewable energy. The solar panels generate an abundance of clean and efficient energy year-round. PV technologies experienced considerable growth rates of up to $70 \%$ in the last year. The growth rate was possible because of low total carbon dioxide emissions and a positive energy balance for PV (Zuser \& Rechberger, 2011). In conjunction with the escalating demand for energy and steady progress in renewable energy technologies, the global environmental concerns opened new venture opportunities for utilization of renewable energy resources (Husain et al., 2018).

During the past decade, the U. S. electricity prices were volatile, making electricity difficult for anyone to plan for that part of their household budget (Razykov et al., 2011). Once homeowners install their solar panels, they no longer must worry about rising electricity prices for the portion of their electricity that comes from solar power. If prices rise, homeowners with solar panels receive a 
bigger and bigger benefit from their intelligent early investment. Using solar energy, U. S. homeowners can reduce overseas oil and gas reliance and increase energy independence. Given that the domestic sources of oil and gas will dwindle during the coming years becomes increasingly urgent to find alternative energy sources to reduce the US reliance on foreign fuel (Marques \& Fuinhas, 2012).

\section{The United States Solar Industry Marketplace}

The National Solar Jobs Census 2021 Report showed that the solar industry added more jobs in 12 months, more rapidly than any other industry, and remained optimistic regarding the solar industry's future (Abareshi, 2011). The U.S. solar industry employed about 100,237 solar workers in 2010. The results from the survey were relevant because the overall expected 12-month growth rate in solar energy industry employment for the entire US economy was only about 1.4\% (Abareshi, 2011). The National Solar Jobs Census 2021 Report drew three principal conclusions about the solar industry:

1) Solar energy workers in the U. S. increased from 93,000 in 2010 to 100,237 in 2011. 2) The overall growth rate of $6.8 \%$ from 2010 was ten times higher than the national average of the unemployment growth rate of $0.7 \%$. 3) Forty-four percent of manufacturing companies expected to add 3473 jobs in 2011, yielding a $14 \%$ growth rate (Abareshi, 2011).

Data from the National Solar Jobs Census 2011 indicated that the solar industry was strong and responsible for thousands of jobs. Solar jobs increased despite an economic downturn. The solar sector outperformed other industry segments in the US economy and experienced tremendous market growth in 10 years. The market growth derives from tax incentives, consumer awareness, price, cost declines, cultural shifts, and governmental support for solar energy policies. The optimism among solar employers during poor economic conditions suggests that solar job growth would continue in the future (Abareshi, 2011).

The fastest-growing energy technology in the US is solar energy (Abareshi, 2011). The market grew to a $\$ 6$ billion industry in 2010 , up $67 \%$ from $\$ 3.6$ billion in 2009. However, despite spectacular growth, the market has slowed due to state-to-state complexities in regulation, incentives, utilities, and financing structures.

In 2010, homeowners in the US purchased 2593 megawatts (MW) of solar electric capacity. The data included approximately 2086 MW of PVs and 507 MW of utility-scale concentrating solar power. In addition to growth in PVs, solar heating capacity grew by $5 \%$ in 2010 , with an estimated 2.4 million square feet of solar heating capacity installed in homes and businesses throughout the US. Moreover, the US ranked fourth in the world for the installation of new solar-electric systems in 2010. As a result, the US was able to become the world's largest solar market, and PV became an increasingly vital energy technology. In sum, solar energy has extensive environmental benefits and is a clean energy source; few other power-generating technologies have a slight ecological impact as PV (Abareshi, 2011). 


\section{Emerging Solar Energy Industry Market in Ohio}

The PV industry is an emerging industry in several states, including Ohio. The PV industry and universities are working to produce second-generation solar panels for the electricity generation of PV cells (SRI International, 2009). The $\mathrm{PV}$ is still an emerging technology and on the verge of cost competitiveness with traditional energy sources. However, PV manufacturing costs were falling; industry stakeholders estimate that, with continued research and development, solar energy became competitive with coal power in 2012.

Solar power has the potential to become a significant part of Ohio's energy future. Ohio is home to 115 businesses and academic universities that invested in the solar energy industry. The PV industry has proven to be the brightest spot in the US economy. The PV industry has experienced a $20 \%$ annual growth rate in the PV markets for many years. In the past 15 years, the PV industry has experienced annual growth rates of $30 \%$ to $40 \%$, and global solar PV installations grew from $125 \mathrm{MW}$ in 1999 to $4500 \mathrm{MW}$ in 2008 (SRI International, 2009).

Ohio's solar energy sector has a solid manufacturing base, and many Ohio businesses are part of the Ohio solar industry supply chain. The supply chain for the solar and PV industries includes manufacturers and system integrators in semi-conducting materials and system design and installation. Ohio's production rose by $50 \%$ during the first three months of 2011, like the top solar-producing states like California and New Jersey (Abareshi, 2011). However, unlike other states, Ohio offers an energy supply chain for businesses operating in the solar energy industry. One of Ohio's advantages is the state's manufacturing industry, a strength-based on a skilled workforce and a central location for advanced energy manufacturing operations. As a result, the solar sector presents an excellent opportunity to promote job creation, increase clean, locally sourced energy availability, and boost the economy. The Solar Foundation highlighted several key steps policymakers, workforce-training providers, and the solar community can take to foster solar industry growth (Abareshi, 2011).

\section{International Solar Energy Marketplace Producers}

In the international solar market, the solar energy markets in China and India received little attention in the past because solar energy overshadows other fossil fuel markets (Kang, 2009). In 2008, China and India developed their solar energy plans. China announced the China Solar Subsidy Plan. India released its draft of a National Solar Mission Plan, which paved the way for these countries' rapid growth of solar-energy markets. China's solar energy market was disappointing until 2007; solar power represented an insignificant portion of total electricity generation, amounting to only $100 \mathrm{MW}$ (Kang, 2009). China's solar energy market entered a new phase in 2009 and grew into a 1000 MW market.

Solar energy is essential to fortify energy security and promote Chinese socio-economic development. Solar thermal energy applications in China concentrate at low and medium temperatures, such as solar water heating, solar cooling, air conditioning, building heating, solar drying, and solar power generating 
(Chen et al., 2017). China focused on silicon-based solar cells technology called the thin film instead of thermal energy for the solar cell. The thin-film solar cell technology is next-generation technology. Thin-film solar cell technology is the next-generation technology in China's research and development phase in solar power generation (Chen et al., 2017). This market experienced penetration by several foreign companies. In comparison, India installed a solar system to manage $100 \mathrm{MW}$, of which $97 \%$ are off-grid systems in remote operation.

In other countries, the solar cell systems operated on a grid-tied system connection. Many international locations operate on a small on-grid solar system. India's approach produced a mere $2.74 \mathrm{MW}$ as of 2008 and connected to the nation's central electrical grid. As reported in the National Solar Mission Plan, the Indian government expanded the capacity of solar power plants to 20,000 MW by 2020 , allocating $\$ 20$ billion over the next 30 years. If the National Solar Mission Plan carried through, the solar power in India would represent one-eighth of today's total power generation (Nykamp et al., 2012).

Storing solar energy-generated power makes electricity available during natural disasters and adverse weather conditions and sells energy reserves to other countries. The growth potential for wind and solar electricity generation prompted Chinese and U. S. utility companies to consider energy storage to manage supply and demand. The world faced dual challenges, such as fossil fuel depletion and carbon dioxide emissions. The use of alternative energy sources like PV panels, wind energy conversion systems create new challenges for an electronic society and the solar industry (Abdulrazzaq \& Ali, 2018). The main challenges facing the world's fossil fuel depletion are coal with carbon capture and storage, nuclear, and renewable energy sources. Solar energy is a minor contributor to the energy constraints in the US because of cost. Nevertheless, the cost reductions in PV production lead solar generation technology to become cost-competitive with fossil fuel energy generation. Therefore, the future trend for this technology is a minor energy distributed generation system in which consumers could function as an energy seller for the local utility companies (AmanorBoadu et al., 2018).

\section{Market Threats Faced by the Solar PV Industry}

Global energy demand would increase over several years, with an energy consumption rate estimated at 20 gigawatts by 2013 (Haley \& Schuler, 2011). Many government policies and business strategies related to solar PV production must overcome regulatory uncertainty in the global PV inverter market (Notton et al., 2010). The global demand caused the solar industry to change from a supplyconstrained to a demand-driven market. The leading factor contributing to the market growth is the utility company's concern regarding power discrepancy. Based on the solar market outlook, both economic and social threats exist within the solar industry.

\section{Economic Threats}

The economic threat to the solar energy industry is the impact from the econo- 
my, capital investments, and solar energy industry solar PV installations. Financial incentives make solar PV-generated electricity more palatable for the consumer than fossil fuel-based electricity. Nineteen states offered several solar project rebates and created renewable energy standards requiring utility companies to purchase a percentage of power from solar sources (Bradford, 2010). Unfortunately, these incentives did not occur equally among the states, and solar companies faced a complex and confusing set of financing options for consumers in different locations. The financing and installation costs for solar PV systems were dropping, but $75 \%$ of solar electricity costs in the US are higher than grid-based electricity over the operating life of the installation. Financing options can take as long as four months to finalize. The complex financing included rebates, tax credits, non-standard contracts, loans, and permits (Sarzynski et al., 2012).

\section{Uncertainty of New Technology Systems}

The role of the demonstration project and trials led to success in the adoption of low carbon energy systems, which in turn produced a comprehensive review of solar PV and wind turbine systems (Munshi et al., 2018). The early stages of the demonstration project and trials involved technology experimentation and subsequent phases of development in reducing the uncertainty in adopting new technologies. The demonstration project and practices overcame innovation uncertainties in renewable energy for electricity supply systems (Munshi et al., 2018). The countries benefiting from innovation in renewable energy for electricity supply systems included the US, countries in the European Union and Japan. In many situations, the governments intervened to mitigate market failure for economic opportunities, societal benefits, and national security. The urgency to implement and reduce carbon emissions from fossil fuels can mitigate or avert catastrophic climate change.

The demonstration project and trials provide lessons about the initial design process and the management and coordination of future measures. In addition, the process allowed others to draw upon the knowledge of companies participating in the demonstration project and trials for solar PV and wind turbine systems (Munshi et al., 2018). Therefore, the demonstration project and practices depend on reassessing the role of bricolage. In this context, the term bricolage is multiple learning processes centered on interactive learning from sciencebased research and experience-based learning (Sarzynski et al., 2012). The Danish used this learning-based process to advance the wind turbine system as a new competitive energy technology. In 2012, the demonstration project and trials database updated to include the European Union, US, and Japanese programs to coordinate the science-based research and experience-based learning.

\section{Research Method and Designs}

A single case design was proper to investigate why a lack of marketing of solar energy systems for residential homeowners exists in Franklin County, OH. A 
qualitative case study design was instrumental in investigating how residential homeowners were affected by the phenomenon. The exploratory nature of this study did not require the testing of statistical variables or hypotheses. A qualitative case study design was optimum because the study focuses on situations or events. The case study would assist a researcher in gathering data of the research questions, analysis, and interpretation regarding residential homeowners' understanding of progress in solar-powered systems (Kline, 2008).

The essence of this case study design was to explore and understand the thematic elements of homeowners' observation related to the main research question (Park \& Park, 2016). The participants' interview response identifies the detail of the phenomena, personal perspective, and emerging thematic expressions (Ross et al., 2018). A case study designed works in many situations to contribute to the knowledge of the individual, group, organizational, social, political, and related phenomena (Yin, 2018). The case study is a standard research method in psychology, sociology, political science, anthropology, social work, business, education, nursing, and community planning. The case study allows the researcher to retain the holistic and meaningful characteristics of real-life events. The case study design can include individual life cycle, group behavior, organizational and management processes, neighborhood change, and maturation of industries (Yin, 2018). The bases of open-ended questions were necessary for the qualitative research design method and data collection instrument (Yin, 2018).

\subsection{Research Design}

The research design appropriate for this study was a qualitative, single-case study research design. The case study was the method of analysis and in-depth description of a bound system. A qualitative single-case study was the most appropriate for this study because of the goal to explore boundaries that are not clear between the outsourcing phenomenon and the claim processing claimprocessing context (Ross et al., 2018).

Face-to-face interviews and audiotape allowed the discovery of themes and characteristics (Yin, 2018). The interviews helped ascertain data for emerging core themes, characteristics, and descriptions, analyzed using NVivo10 qualitative data analysis software. The NVivo10 software facilitated an analysis of the data to identify trends and patterns in homeowners' understandings of solar energy, particularly concerning the marketing strategy of solar energy systems sold for residential use.

\subsection{Population and Sampling}

In a qualitative case study, a sample size of twenty participants is appropriate to fulfill the requirement of extracting meaningful data (Ross et al., 2018). The study involved a purposeful sample in investigating the marketing strategy of solar energy systems sold for residential use. A purposive sampling occurs when a researcher deliberately chooses participants because of their unique characte- 
ristics concerning the subject matter (Saunders et al., 2015). The process involves investigating the knowledge of the homeowners residing in the targeted communities.

The study participants came from the larger population consisting of residential homeowners living within Franklin County, OH. The participants were a mix of married and single households with children, ethnically diverse, and middle-income residents. The residential homeowners articulated a representation of the thematic views of the area residents. In addition, the homeowners provided a level of awareness regarding the phenomena studied and communicated possible collaborative opportunities between the community and the solar industry.

Marshall and Rossman (2016) described a method of purposeful sampling design to sample the target population, which consists of the following: 1) target population, 2) parameters of interest, 3) sample frame, 4) sampling method, and 5) sample size. The adequacy of sample size for case study research is relative and depends on the research question, possible individuals, and measurements of interest (Yazan, 2015). The information weighs the advantages and disadvantages regarding the availability of solar-energy alternatives systems. The success of this study depended on the availability of residential homeowners participating in the data gathering process (Marshall \& Rossman, 2016).

A sampling population of 20 residential homeowners derived from 50 registered homeowners residing within Northwest Point North, Galloway, OH. The residential community was the basis for selecting the area and the participants during the discovery process of answering the research question and problem statement (Yin, 2018). Each homeowner's participation required approximately 30 minutes for an initial face-to-face interview regarding residential home use of solar energy systems.

In a qualitative case study, a sample size of 20 participants is appropriate to fulfill the requirement of extracting meaningful data (Marshall \& Rossman, 2016). The study involved a purposeful sample in investigating the marketing strategy of solar energy systems sold for residential use. A purposive sampling occurs when a researcher deliberately chooses participants because of their unique characteristics concerning the subject matter (Marshall \& Rossman, 2016). The process involved investigating the knowledge of the homeowners residing in the targeted communities.

The study participants came from the larger population consisting of residential homeowners living within Franklin County, OH. The participants were a mix of married and single households with children, ethnically diverse, and middle-income residents. The residential homeowners articulated a representation of the thematic views of the area residents. The homeowners provided awareness concerning the phenomena studied and communicated possible collaborative opportunities between the community and the solar industry. I chose a minimum sample of 20 homeowners in conducting the case study. The process al- 
lowed me to reach a thematic saturation point, which was sufficient at deriving a thematic saturation (Yin, 2018).

Marshall and Rossman (2016) described a method of purposeful sampling design to sample the target population, which consists of the following: 1) target population, 2) parameters of interest, 3) sample frame, 4) sampling method, and 5) sample size. The adequacy of sample size for case study research is relative and depends on the research question, possible individuals, and measurements of interest (Yin, 2018). The information weighs the advantages and disadvantages regarding the availability of solar-energy alternatives systems. The success of this study depended on the availability of residential homeowners participating in the data gathering process (Marshall \& Rossman, 2016).

\subsection{Data Collection}

A researcher must use a primary instrument for data collection and ask the interview questions unbiased (Yin, 2018). Therefore, open-ended interview questions for data collection were the primary collection method for the qualitative study. The questions elicited an open-ended and in-depth response from a face-to-face interview with each participant.

Closed-ended questions are not an option for a qualitative study because the questions may limit the participant responses (Yin, 2018). However, an openended interview was an appropriate strategy given the participants' levels of knowledge regarding the research topic (Marshall \& Rossman, 2016). Developing and defining the interview questions are the two most crucial steps in research to ensure the questions provide substance and form (Yin, 2018).

In contrast, the commonplace narrative concepts were of 1) time; condition, and place; 2) the narrative structuring of past, present; and 3) future was integral to the interview format (Van den Berg \& Struwig, 2017). The interview questions provided the foundational framework for in-depth interviews. The interview questions presented in the instrument allowed the study to maintain the flexibility described in the discussion of design considerations. The open-ended questions expanded the depth of knowledge regarding the phenomenon. They allowed for a comprehensive analysis of data collected via hand-written notes, a recording device, or a written response.

The use of a pilot study was necessary to align the foundation of the research question. The use of interview questions presented as the instrument method allowed the flexibility described in the discussion of design considerations. The use of open-ended questions revealed various opinions among the homeowners regarding the lack of marketing of solar energy systems for residential use. The data analysis from the pilot study supported the research conclusion to conduct a full-blown interview.

\subsection{Data Collection Technique}

Open-ended interview questions can eliminate a researchers' bias by avoiding 
leading answers. Qualitative data derived through various methods, such as observations, interviews, and document discovery, are other unbiased approaches (Yin, 2018). A researcher requires emotional awareness of possible threats to the study's objectivity (Windsong, 2018). The interviews served as the primary data collection technique, and NVivo10 qualitative data-analysis software identified thematic relationships within the data. Opened-end interviews were the best way to reflect the viewpoints of a given population (in this case, the County's homeowners). The qualitative design assisted with understanding the phenomenon and the potential implications across the region (Windsong, 2018). The five participants received questions to determine if the interview questions were clear and concise. Participants read each of the six interview questions. Participant responses suggested that the interview protocol was appropriate for the qualitative case study. The participants provided constructive feedback regarding the order of questions, clarity, and the interview process.

\subsection{Data Organization Techniques}

An organization technique such as an interview guide or protocol assists a researcher in maintaining consistency within the data collection process (Yin, 2018). For example, several empirical studies utilized data organization techniques in solar and green power technology, maintained detailed field notes, categorized the study's collected documents, and structured the interview process (Phillips et al., 2017). In addition, the electronic management system allowed the flexibility to manipulate and query data within the proposed theory framework (Phillips et al., 2017).

\subsection{Data Analysis Technique}

NVivo10 qualitative data analysis software allowed a systematic data analysis involving the development of relevant themes. The idea of performing qualitative research originated from the understanding that qualitative data emanates from verbal and text information. A qualitative data analysis technique explained the phenomena and shaped the accumulated data through the development of thematic elements and conclusions (East, 2016). Using open-ended interview questions was an appropriate method for conducting a case study (Yin, 2018). The interview questions for the study allowed participants to express their opinions. The data from the interviews were uploaded into NVivo10 qualitative data analysis software for analysis to yield the study's general themes. The data results integrate into a narrative for consistency with the research questions (Vaughn \& Turner, 2016). The analysis method allowed a researcher to identify patterns or themes in the data and provide insights reflecting a deeper understanding of the phenomenon (Vaughn \& Turner, 2016). The NVivo10 qualitative data analysis software used a content analysis platform to determine the themes and patterns derived from the participants' interviews. The content follows a process for coding and drawing inferences from the text based on res- 
ponses to open-ended measurement questions to measure the semantic content (Marshall \& Rossman, 2016). Coding transcripts provided the opportunity to search for patterns among participants and discard data with similarities to other supportive information (East, 2016).

\section{Findings, Summary, and Conclusions}

The study participants provided critical insight into the lack of solar industry marketing strategies in promoting advanced energy systems technology for residential use. In addition, the study results were essential to describe the participant viewpoint and familiarities the primary research question related to the level of homeowner understanding regarding the availability of solar energy systems. In the following subsections, the summary of the Raw Data of Collected Interview Verbatim Responses presented the thematic textural-structural descriptions of the homeowner responses.

\section{Interview Question 1}

The first interview question was, "What do homeowners view as the key benefits of installing a solar energy system?"

Summary analysis of homeowner viewpoints. The homeowners identified the environment as the most important benefit of installing a solar energy system. Based on the analysis of the homeowners' responses, $75 \%$ of the participants suggested that the maximum benefit of installing a solar energy system was protecting the environment. The second most significant response related to finance; $50 \%$ of the participants noted that an essential benefit of a solar energy system was reducing energy cost, saving money, and achieving a lower electricity bill. Finally, participant responses revealed that alternative energy represented one of the leading issues toward social change.

\section{Interview Question 2}

The second interview question was, "What factors would convince a residential homeowner to purchase and install a solar energy system?"

Summary analysis of homeowner viewpoints. The homeowner responses revealed that $75 \%$ of the participants believed the solar energy system was expensive to own. The homeowners feared the financial burden of paying for a solar energy system, and $10 \%$ believed they would have to sacrifice an essential quality of life. The data analysis revealed that $50 \%$ of the participants viewed the cost of equipment as having a significant impact on their decision to purchase a solar energy system. If solar energy systems became more affordable, the study's findings showed that the cost and equipment would play a vital role in their decision-making process.

\section{Interview Question 3}

The third interview question was, "How much do cost and equipment affect your decision in purchasing a solar energy system

Summary analysis of homeowner viewpoints. The homeowners' responses to question three revealed that $50 \%$ of the participants thought using renewable 
energy to address energy consumption was an excellent idea. The data analysis revealed that $100 \%$ of the participants stated the cost and equipment would affect the final decision to purchase a solar energy system. The data analysis indicated a minority view: $25 \%$ of the participants felt reluctant to make any new changes without knowledge of the solar energy system and equipment installation. The finding suggested that many homeowners felt that solar energy systems were in early development stages, making people generally uncomfortable. The homeowners believed more information was necessary concerning financing a solar energy system and comparing a solar energy system to conventional energy sources such as natural gas and crude oil.

\section{Interview Question 4}

The fourth interview question was, "What impact would government incentive funding have on your decision to purchase and install a solar energy system?"

Summary analysis of homeowner viewpoints. The analysis revealed that $75 \%$ of the participants thought government incentives would affect their decision to invest in solar energy. The homeowners' responses indicated that $50 \%$ of the participants believed that such incentives were a government obligation. Consumers thought that incentives would significantly affect the overall decision to purchase a solar energy system. The data analysis revealed that $15 \%$ of the participants felt that government incentives were unavailable to homeowners. The finding showed that homeowners wanted additional information about government incentive options for solar energy systems.

\section{Interview Question 5}

The fifth interview question was, "What information do homeowners want to hear from the solar industry regarding alternative energy systems?"

Summary analysis of homeowner viewpoints. The homeowner responses revealed that $100 \%$ of the participants wanted to hear more from the solar industry regarding the availability of solar energy systems for residential use. The data analysis revealed that $50 \%$ of the participants had no information or knowledge regarding solar energy systems and were unaware of advancements in alternative energy systems. These findings suggested that many homeowners feel the solar industry is not doing enough to provide homeowners with the advantages of solar energy systems compared to the use of fossil fuel systems. The data analysis revealed that $20 \%$ of the participants would like the solar industry to provide a comprehensive list of pros and cons and the technological advancements made with solar energy technology.

\section{Interview Question 6}

The sixth interview question was, "What are customer perceptions of consumer awareness of solar energy systems?"

Summary analysis of homeowner viewpoints. The analysis revealed that $100 \%$ of the participants stated minimal consumer awareness of solar energy systems. In addition, $100 \%$ of the participants wanted information concerning the 
latest advancements in alternative energy systems for residential use. Fifty percent of participants believed that the solar industry could do more to promote the availability of solar energy systems for residential use. The study findings indicated that $50 \%$ of the participants wanted information about alternative energy sources to come directly from the solar industry and not from the big oil and utility companies. The homeowners wanted to hear solar industry companies' perspectives on the future of solar energy systems for residential use.

\section{Thematic Textural-Structural Description}

The single case study applied an investigative research method to the collected data derived from face-to-face interviews of a purposive sample of 20 homeowners. The data analyzed from interviews received grouping into themes using NVivo10 qualitative data-analysis software. The textual-structural description of the study interviews may provide solar industry leaders with information and insight into marketing strategies for promoting solar energy systems for residential use. Each of the 20 participant interviews received transcription verbatim from recorded interviews and imported into NVivo10 qualitative data-analysis software for coding and analysis. The NVivo10 qualitative data-analysis software coded the transcribed responses into descriptive patterns of generalized themes. The participant responses revealed three generalized themes: benefits of solar energy, residential homeowner views, and information regarding solar energy systems.

\section{Composite Theme Description}

The themes emerged using the NVivo10 qualitative data analysis and resulted in a composite description that identified three primary theme meanings. Each of the twenty participants answered six open-ended interview questions; after the twelfth participant's responses, the study reached saturation. The participant interviews continued with the purposive sample of twenty homeowners drawn from the population.

\section{Interpretation of Thematic Findings}

Theme 1: Benefits of Solar Energy. The first emerging theme from data analysis was the benefits of solar energy.

Summary analysis of homeowner responses. The homeowners' responses reflected in Theme 1 revealed that $50 \%$ of the participants felt that solar energy was good for the environment and communities around the country. The homeowners expressed concerns about the protection of a clean environment. The results indicated that $50 \%$ of the participants suggested the maximum benefit of solar energy was protecting the environment. The homeowners believed that most solar energy systems resulted in lower costs of electricity and saving money.

Theme 2: Residential Homeowner Views. The second emerging theme from data analysis was the residential homeowner views. The interview responses allowed an analysis of the cost concerning the lack of a marketing strategy related to residential solar energy systems. 
Note: Table 8 reflects the analysis of homeowners' opinions for Theme 2.

Summary analysis of homeowner responses. The responses reflected in Theme 2 revealed that $100 \%$ of the participants felt that more information was necessary regarding solar energy technology's cost, advantages, and disadvantages. The homeowners wanted financial savings, maintenance, durability, dependability, future expenses, quality of system components, and overall system effectiveness. The data analysis revealed that $75 \%$ of the participants felt solar energy systems were a better alternative than fossil fuel systems, but the initial investment cost was three times high.

Theme 3: Information Regarding the Use of Solar Energy Systems. The third emerging theme from data analysis was information for the homeowner regarding solar energy systems. Again, the interview responses enabled a communication breakdown concerning the lack of marketing strategies targeted at homeowners.

Summary analysis of homeowner responses. The homeowners' responses reflected in Theme 3 reveal that $100 \%$ of the participants felt more information was necessary to comprehend the advantages of using solar energy systems. The data analysis revealed an important finding that homeowners want to hear additional details regarding solar energy systems. The study results indicated that $50 \%$ of participants wanted to directly receive information about alternative energy sources from the solar industry. The participants wanted to hear the news from the companies that produce these systems and listen to their perspectives concerning the future of solar energy systems.

\section{Negative Case Analysis}

A negative case analysis measures a research study's trustworthiness and the necessity for evaluating the study's worthiness (Lincoln \& Guba, 1985). The examination of negative cases was integral to strengthening the study by aiding in establishing 1) Credibility, which describes or understands the phenomena of interest from the participant's point of view, 2) Transferability, which enhances transferability by doing a thorough job of describing the research context and the assumptions that were central to the research, 3) Dependability, which ensures repeatability that relies on the assumption of repeatability by obtaining the same results when observing the same thing twice, 4) Confirmability means conducting a data audit that examines the data collection and analysis procedures for potential bias or distortions (Marshall \& Rossman, 2016).

The negative case analysis involved data that do not support or appear to contradict patterns or explanations emerging from data analysis for reliability and validity by implementing some type of verification strategy and self-correcting during the conduct of the study (Naidu \& Prose, 2018). The great strength of qualitative research was the methodology feeding directly back to the analysis process (Rose \& Johnson, 2020). Many researchers conducting qualitative research can take advantage of the newly discovered data to check the quality of categories and explanations. The study interview questions yielded similar themes 
across participant responses, supporting the reliability of the instrument. In the study, the new data yielded a theoretical explanation through a process as a case study.

A negative case analysis does not support the data collection that comes at the end of the data testing cycle to confirm the instrument's reliability (Abdalla et al., 2018). However, data generated from the participants support the new data confirming the explanations, and the compilation of the more prominent responses provided by participants includes the textural description section of the study (Rose \& Johnson, 2020).

The reliability of the study validity was established by following a repeatable interview protocol and questions posed to all participants, consequently resulting from similar opinions of the event. Case studies are the preferred research method in a qualitative study when how and why questions exist (Yin, 2018). The validity of the case study used data triangulation to arrive at data consistency from the source data. Triangulation refers to using more than one approach to the investigation of a research question to enhance confidence in the ensuing findings (Windsong, 2018).

The data collection method for a case study design used in-depth interviews as the data source. Data collection methods include tests, surveys, interviews, attitude scales, observations, and journals (Windsong, 2018). During the data collection stage, consistent views from the homeowners to compare areas of agreement and divergence were evident. The study's validity used data triangulation methods such as in-depth interviews, researcher observations, and literature review for consistency in the data sources. Thus, the data source inconsistency is not a weakness in the evidence of the source. Still, research should look upon this as an opportunity to discover a deeper meaning in the data analysis (Windsong, 2018).

\subsection{Applications to Professional Practice}

The Ohio Department of Development identified various energy diversification measures that improve the business application in the solar energy industry in Ohio (Ohio Department of Development, 2021). The study findings suggested that the research insights may prove helpful to business leaders and those responsible for establishing and implementing an energy diversification program. The Ohio Department of Development developed four application measures for understanding and addressing the solar energy marketing strategy business problem in Ohio. The first measure involves establishing communication with Ohio's stakeholders to advance Ohio's solar and wind distribution chain. The second measure consists of removing restricted policies that affect the state and local governments to stimulate solar energy development in Ohio. The third measure involves promoting the visibility of Ohio's solar and wind energy supply chain on a national and international level. The fourth measure involves providing consumers general information and cost-benefits analysis of investing in solar 
energy.

The energy diversification measures would assist local communities throughout Ohio to focus on initiatives that yield the most valuable sustainable energy solution. The business strategy would reduce the lack of knowledge about solar energy systems and establish a statewide acceptance of alternative energy systems. These measures could promote economic diversification and social change (Ohio Department of Development, 2021).

For instance, St. Lucie County, Florida, developed a business initiative that offered residents the ability to reduce their utility bills by saving energy. The County introduced the Clean Energy Loan Program, offered through the Solar and Energy Loan Fund (SELF) in 2010 (St. Lucie County, 2021). SELF-provided the County residents with a revolving loan program with terms more favorable than those received from traditional banks. SELF offered the County residents financial terms for several types of energy-efficient and renewable energy options that included 1) weatherization, 2) replacement of inefficient air-conditioning systems, 3) window tinting, 4) light-emitting diodes (LED) lighting, 5) cool roof construction, and 6) installation of solar thermal and solar PV systems (St. Lucie County, 2021).

The solar energy industry could emulate a SELF-program within Franklin County, $\mathrm{OH}$ as a business model for a strategic marketing campaign to promote solar energy systems for residential use. The solar industry could lead the nation to establish a lending institution with a social mission, provide low-cost financing, and make energy-saving property improvements. The study results could contribute in various ways to the professional literature, where little theory or no research exists to explain the viewpoints of residential homeowners. The study results may provide the effectiveness of marketing strategies for solar energy systems, informing solar energy business leaders regarding the promotion of solar energy systems.

\subsection{Implications for Social Change}

The implications for positive social change include the potential to identify a marketing strategy to promote alternative energy for residential use. The use of electricity, natural gas, and petroleum products have become necessities of life in modern society; however, prices are rising and have taken a toll on the poorest of citizens and individuals with fixed incomes (Andrews, 2008). The findings presented in the study promoted social change. The need for change in Ohio includes exploring the business strategies for implementing initiatives, such as clean energy. In addition, the consumers may benefit positively by affecting social change for residential homeowners in Franklin County, $\mathrm{OH}$, by promoting the need for energy diversification other than fossil fuel-based electricity generation. The promotion of energy diversification includes solar, wind, and thermal energy as alternatives.

Fossil fuel-based electricity generation poses severe risks to public health be- 
cause of the greenhouse gases and increased respiratory illness caused by air pollutants. Solar energy systems produce no pollution and help to improve air quality and public health. Solar energy systems can build strong and diverse economic benefits that vary across institutions, cultures, and commercial sectors and can provide significant economic benefits to Ohioans.

\subsection{Recommendations for Action}

The research aimed to explore the extent of residential homeowners' awareness of solar energy systems and knowledge about the solar industry technology advancements regarding solar energy systems. The study concluded that homeowners are mainly unaware of the ongoing phenomenon. In addition, the study results concluded that the solar industry's lack of marketing strategies implemented in Franklin County, OH. The finding should prompt solar energy leaders to develop a marketing strategy to promote energy diversification solutions for residential users. The literature review revealed no empirical studies on homeowners' views regarding marketing strategies for residential solar energy systems. The study's findings presented an opportunity for solar industry business leaders and small companies that produce solar system components to build upon their body of knowledge and recommend actions that promote sustainable and renewable energy systems for residential communities throughout the state of Ohio. Solar energy technology came in three basic solar energy system types: active, passive, and hybrid. The study emphasized the dynamic solar system because of PV panels on rooftops of residential homes.

The global energy demand has currently grown beyond the limits of installable generation capacity. There are many available renewable energy sources; solar energy systems are a promising alternative and extensively available for residential use. Passive solar power systems are more cost-competitive with other energy sources and serve as a new technology for energy sustainability for homeowners. The application of passive solar energy devices can benefit the environment, the economy of the nation, and the lives of millions of underprivileged individuals in developing countries (Devabhaktuni et al., 2013).

\subsection{Recommendations for Further Study}

A future quantitative study may increase the awareness of solar power systems because electricity remains a necessity for daily living and widening the scope of the study by introducing the technological advancement of solar generation. In addition, quantitative research could further explore and disseminate additional factors concerning renewable energy systems. The elements would include analyzing solar systems design concepts, different consumer views about solar energy systems, and conventional fossil fuel-generated energy systems.

Solar energy industry leaders must capitalize on the opportunity to transform the nation's alternative energy plan initiative (Meadowcroft et al., 2018). The potential impact of redistributing the nation's alternative energy plan must in- 
clude provisions to protect the most vulnerable consumers in society while securing the nation's electrical grid. The infusion of renewable energy such as solar power into the power grid increases the interest of consumers (Barsoum \& Lee, 2013). The study could assist in creating awareness and highlight the different types of renewable energy options. Fossil fuel resources remain the dominant source of primary energy generation for the next 25 years.

\subsection{Summary and Study Conclusion}

The results from the analysis revealed marketing strategies implemented by the solar industry are insufficient to promote solar energy systems for residential use in Franklin County, Ohio. In-depth interviews investigated the marketing strategies and the participant opinions analyzed using NVivo10 qualitative data analysis software. The NVivo10 process helped analyze the qualitative data to yield a greater insight from the participant's opinions.

The product choice and communication channels empower millions of consumers to take advantage of emerging market products and services (Atsmon et al., 2012). Homeowners have become a powerful consumer group for the emerging solar industry market. Consumer empowerment has increased. Three factors influence the consumer's decision-making process:

Initial brand. The initial brand consideration set was likely much smaller initially, which consumers like to switch to another brand later if that was not in their initial setting.

Word of mouth. Word of mouth plays an essential role because of the higher rate of first-time buyers and a shorter history of familiarity with brands. Word of mouth includes a culture of societal validation and a fragmented media landscape.

In-store experience. The in-store experience influenced a high volume of consumers in their final decisions, which many consumers rarely miss the handson in-store expertise when making the final decisions.

Section 1 highlighted the business problem and provided an analysis of the marketing strategy by the solar industry within local communities throughout the state of Ohio. The history of solar energy as an abundant and reliable source of energy produces electricity to meet the challenges of growing energy demand. Section 2 describes the findings that confirm the certainty of the phenomena and serve as the primary focus of the research.

Business leaders across the solar energy sector needed to implement solutions for marketing solar systems as alternatives for a clean and renewable energy source. Recommendations that would help residential homeowners have access to better energy choices include: 1) improve the availability of solar-energy systems for energy independence for Ohioans, 2) increase awareness of different energy-powered systems, 3) avoid rising fuel costs, 4) reduce the US dependence on foreign fuel sources, and 5) reduce the carbon emissions footprint. 


\section{Conflicts of Interest}

The authors declare no conflicts of interest regarding the publication of this paper.

\section{References}

Abareshi, A. (2011). The Antecedents of IT-Business Alignment in Manufacturing Firms. International Journal of Business Information Systems, 8, 322-337. https://doi.org/10.1504/ijbis.2011.042412

Abdulrazzaq, A. A., \& Ali, A. H. (2018). Efficiency Performances of Two MPPT Algorithms for PV System with Different Solar Panels Irradiances. International Journal of Power Electronics and Drive System (IJPEDS), 9, 1755-1764.

https://doi.org/10.11591/ijpeds.v9.i4.pp1755-1764

Abdalla, M., Oliveira, L., Azevedo, C., \& Gonzalez, R. (2018). Quality in Qualitative Organizational Research: Types of Triangulation as a Methodological Alternative. Administration: Teaching and Research, 19, 66-98. https://doi.org/10.13058/raep.2018.v19n1.578

Amanor-Boadu, J. M., Abouzied, M. A., \& Sánchez-Sinencio, E. (2018). An Efficient and Fast Li-Ion Battery Charging System Using Energy Harvesting or Conventional Sources. IEEE Transactions on Industrial Electronics, 65, 7383-7394.

https://doi.org/10.1109/tie.2018.2793243

Andrews, C. J. (2008). Energy Conversion Goes Local: Implications for Planners. Journal of the American Planning Association, 74, 231-254. https://doi.org/10.1080/01944360801993531

Arizona Solar Energy Association (2011). Innovative Policy Advocacy. Sustainable Business Opportunities. Engaging and Educating Stakeholders. https://www.ariseia.org/about.html

Atsmon, Y., Kuentz, J., \& Seong, J. (2012). Building Brands in Emerging Markets. Mckinsey Quarterly, 4, 50-57. https://www.mckinsey.com

Barsoum, N., \& Lee, C. Z. (2013). Simulation of Power Flow and Protection of a Limited Bus Grid System with Injected Solar Power. Energy and Power Engineering, 5, 59-69. https://doi.org/10.4236/epe.2013.51008

Bazmi, A. A., \& Zahedi, G. (2011). Sustainable Energy Systems: Role of Optimization Modeling Techniques in Power Generation and Supply: A Review. Renewable and Sustainable Energy Reviews, 15, 3480-3500. https://doi.org/10.1016/j.rser.2011.05.003

Bradford, T. (2010). A Lifetime in the Solar Industry. Greentech Media Solar Summit 2010. http://www.greentechmedia.com

Branker, K., Pathak, M. J. M., \& Pearce, J. M. (2011). A Review of Solar Photovoltaic Levelized Cost of Electricity. Renewable and Sustainable Energy Reviews, 15, 4470-4482. https://doi.org/10.1016/j.rser.2011.07.104

Chen, J., Liu, W., Jiang, D., Zhang, J., Ren, S., Li, L., Xiaokang \& Li, Xilin Shi. (2017). Preliminary Investigation on the Feasibility of a Clean CAES System Coupled with Wind and Solar Energy in China. Energy, 127, 462-478.

https://doi.org/10.1016/j.energy.2017.03.088

Christensen, M. C. (1997). The Innovator's Dilemma: When New Technologies Cause Great Firms to Fail. Harvard Business School Press.

Curtiss, E. T., \& Eustis, E. (2008). The Enterprise Goes Green Worldwide Commercial Solar Panel Market Shares Strategies, and Forecasts 2008 to 2014. 
https://wintergreenresearch.com

Dan, Y., \& Hang, C. C. (2010). A Reflective Review of Disruptive Innovation Theory. International Journal of Management Reviews, 12, 435-452. https://doi.org/10.1111/j.1468-2370.2009.00272.x

Davis, M. C., Challenger, R., Jayewardene, D. N. W., \& Clegg, C. W. (2013). Advancing Socio-Technical Systems Thinking: A Call for Bravery. Applied Ergonomics, 45, 171180. https://doi.org/10.1016/j.apergo.2013.02.009

Devabhaktuni, V., Alam, M., Shekara S, Reddy Depuru, S., Green II, R. C., Nims, D., \& Near, C. (2013). Solar Energy: Trends and Enabling Technologies. Renewable and Sustainable Energy Reviews, 19, 555-564. https://doi.org/10.1016/j.rser.2012.11.024

East, R. (2016). Bias in the Evaluation of Research Methods. Marketing Theory, 16, 219231. https://doi.org/10.1177/1470593115609797

Haley, U. V., \& Schuler, D. A. (2011). Government Policy and Firm Strategy in the Solar Photovoltaic Industry. California Management Review, 54, 17-38.

https://cmr.berkeley.edu

https://doi.org/10.1525/cmr.2011.54.1.17

Kang, H. (2009). Solar Energy Markets in China and India. SERI Quarterly, 2, 104-107. https://www.proquest.com/scholarly-journals/solar-energy-markets-china-india/docvie w/218914210/se-2?accountid $=7374$

Husain, A. A., Hasan, W. Z. W., Shafie, S., Hamidon, M. N., \& Pandey, S. S. (2018). A Review of Transparent Solar Photovoltaic Technologies. Renewable and Sustainable Energy Reviews, 94, 779-791. https://doi.org/10.1016/j.rser.2018.06.031

Kline, W. (2008). Developing and Submitting Credible Qualitative Manuscripts. Counselor Education and Supervision, 47, 210-217. https://doi.org/10.1002/j.1556-6978.2008.tb00052.x

Lincoln, Y. S., \& Guba, E. G. (1985). Naturalistic Inquiry. Sage.

Lukasiak, L., \& Jakubowski, A. (2010). History of Semi-Conductors. Journal of Telecommunications and Information Technology, 1, 3-9.

http://yadda.icm.edu.pl/baztech/element/bwmeta1.element.baztech-article-BATA-0008 $\underline{-0020}$

Lupangu, C., \& Bansal, R. C. (2017). A Review of Technical Issues on the Development of Solar Photovoltaic Systems. Renewable and Sustainable Energy Reviews, 73, 950-965.

https://doi.org/10.1016/j.rser.2017.02.003

Mäki, A., Valkealahti, S., \& Leppäaho, J. (2011). Operation of Series-Connected SiliconBased Photovoltaic Modules under Partial Shading Conditions. Progress in Photovoltaics: Research and Applications, 20, 298-309.

https://doi.org/10.1002/pip.1138

Marques, A. C., \& Fuinhas, J. A. (2012). Is Renewable Energy Effective in Promoting Growth? Energy Policy, 46, 434-442. https://doi.org/10.1016/j.enpol.2012.04.006

Marshall, C., \& Rossman, G. (2016). Designing Qualitative Research (5th ed.). Sage.

Meadowcroft, J., Stephens, J. C., Wilson, E. J., \& Rowlands, I. H. (2018). Social Dimensions of Smart Grid: Regional Analysis in Canada and the United States. Introduction to Special Issue of Renewable and Sustainable Energy Reviews. Renewable and Sustainable Energy Reviews, 82, 1909-1912.https://doi.org/10.1016/j.rser.2017.06.106

Mekhilef, S., Saidur, R., \& Safari, A. (2011). A Review on Solar Energy Use in Industries. Renewable and Sustainable Energy Reviews, 15, 1777-1790.

https://doi.org/10.1016/j.rser.2010.12.018 
Moustakas, K., Loizidou, M., Rehan, M., \& Nizami, A. S. (2020). A Review of Recent Developments in Renewable and Sustainable Energy Systems: Key Challenges and Future Perspective. Renewable and Sustainable Energy Reviews, 119, Article ID: 109418. https://doi.org/10.1016/j.rser.2019.109418

Munshi, A. H., Sasidharan, N., Pinkayan, S., Barth, K. L., Sampath, W. S., \& Ongsakul, W. (2018). Thin-Film CdTe Photovoltaics-The Technology for Utility Scale Sustainable Energy Generation. Solar Energy, 173, 511-516. https://doi.org/10.1016/j.solener.2018.07.090

Naidu, T., \& Prose, N. (2018). Re-Envisioning Member Checking and Communicating Results as Accountability Practice in Qualitative Research: A South African Community-Based Organization Example. Forum Qualitative Sozialforschung, 19.

National Renewable Energy Laboratory (2012). Photovoltaic Research. https://www.nrel.gov/

Nayak, P. K., Mahesh, S., Snaith, H. J., \& Cahen, D. (2019). Photovoltaic Solar Cell Technologies: Analysing the State of the Art. Nature Reviews Materials, 4, 269-285.

https://doi.org/10.1038/s41578-019-0097

Notton, G., Lazarov, V., \& Stoyanov, L. (2010). Optimal Sizing of a Grid-Connected PV System for Various PV Module Technologies and Inclinations, Inverter Efficiency Characteristics and Locations. Renewable Energy, 35, 541-554. https://doi.org/10.1016/j.renene.2009.07.013

Nykamp, S., Andor, M., \& Hurink, J. L. (2012). Standard' Incentive Regulation Hinders the Integration of Renewable Energy Generation. Energy Policy, 47, 222-237. https://doi.org/10.1016/j.enpol.2012.04.061

Ohio Department of Development (2021). Ohio Solar and Wind Working Group Request for Proposal. https://development.ohio.gov/wps/portal/gov/development/

Park, J., \& Park, M. (2016). Qualitative versus Quantitative Research Methods: Discovery or Justification? Journal of Marketing Thought, 3, 2-7. https://doi.org/10.155/jmt2016.03.01.1

Phillips, A., Borry, P., \& Shabani, M. (2017). Research Ethics Review for the Use of Anonymized Samples and Data: A Systematic Review of Normative Documents. Accountability in Research: Policies \& Quality Assurance, 24, 483-496. https://doi.org/10.1080/08989621.2017.1396896

Razykov, T. M., Ferekides, C. S., Morel, D., Stefanakos, E., Ullal, H. S., \& Upadhyaya, H. M. (2011). Solar Photovoltaic Electricity: Current Status and Future Prospects. Solar Energy, 85, 1580-1608. https://doi.org/10.1016/j.solener.2010.12.002

Rose, J., \& Johnson, C. W. (2020). Contextualizing Reliability and Validity in Qualitative Research: Toward More Rigorous and Trustworthy Qualitative Social Science in Leisure Research. Journal of Leisure Research, 51, 432-451.

https://doi.org/10.1080/00222216.2020.1722042

Ross, M. W., Iguchi, M. Y., \& Panicker, S. (2018). Ethical Aspects of Data Sharing and Research Participant Protections. American Psychologist, 73, 138-145. https://doi.org10.1037/amp0000240

Sarzynski, A., Larrieu, J., \& Shrimali, G. (2012). The Impact of State Financial Incentives on Market Deployment of Solar Technology. Energy Policy, 46, 550-557. https://doi.org/10.1016/j.enpol.2012.04.032

Saunders, M. N. K., Lewis, P., \& Thornhill, A. (2015). Research Methods for Business Students (7th ed.). Pearson Education Limited. 
SRI International (2009). Making an Impact: Assessing the Benefits of Ohio's Investment in Technology-Based Economic Development Programs. https://development.ohio.gov

St. Lucie County (2021). Solar and Energy Loan Fund. https://www.stlucieco.gov/departments-services/a-z/community-services/housing/solar -energy-and-loan-fund-self

Uddin, K., Gough, R., Radcliffe, J., Marco, J., \& Jennings, P. (2017). Techno-Economic Analysis of the Viability of Residential Photovoltaic Systems Using Lithium-Ion Batteries for Energy Storage in the United Kingdom. Applied Energy, 206, 12-21. https://doi.org/10.1016/j.apenergy.2017.08.170

Ulsrud, K., Winther, T., Palit, D., Rohracher, H., \& Sandgren, J. (2011). The Solar Transitions Research on Solar Mini-Grids in India: Learning from Local Cases of Innovative Sociotechnical Systems. Energy for Sustainable Development, 15, 293-303. https://doi.org/10.1016/j.esd.2011.06.004

U. S. Department of Energy (2021). Energy Sources. http://www.energy.gov/

Van den Berg, A., \& Struwig, M. (2017). Guidelines for Researchers Using an Adapted Consensual Qualitative Research Approach in Management Research. Electronic Journal of Business Research Methods, 15, 109-119.

https://www.academic-conferences.org/ejournals.htm

Vaughn, P., \& Turner, C. (2016). Decoding via coding: Analyzing qualitative text data through thematic coding and survey methodologies. Journal of Library Administration, 56, 41-51. https://doi.org/10.1080/01930826.2015.1105035

Windsong, E. A. (2018). Incorporating Intersectionality into Research Design: An Example Using Qualitative Interviews. International Journal of Social Research Methodolo$g y$, 21, 135-147. https://doi.org/10.1080/13645579.2016.1268361

Yazan, B. (2015). Three Approaches to Case Study Methods in Education: Yin, Merriam, and Stake. The Qualitative Report, 20, 134-152. https://doi.org/10.46743/2160-3715/2015.2102

Yin, R. K. (2018). Case Study Research and Applications: Design and Methods (6th ed.). Sage.

Zuser, A., \& Rechberger, H. (2011). Considerations of Resource Availability in Technology Development Strategies: The Case Study of Photovoltaics. Resources, Conservation and Recycling, 56, 56-65. https://doi.org/10.1016/j.resconrec.2011.09.004 